\title{
INTERCULTURALITY IN THE MODERN RUSSIAN LINGUISTIC LANDSCAPE
}

\author{
Ekaterina Yu. Protassova \\ University of Helsinki (Helsinki, Finland) \\ ORCID ID: https://orcid.org/0000-0002-8271-4909
}

\begin{abstract}
A bstract. The purpose of this article is to give a quick overview of intercultural tendencies in certain Russian regions' modern linguistic landscapes: where they can be found, why languages other than Russian are used, what the purpose of their use is, and who uses them. The material for this study includes several thousand photos taken between 2010 and 2018 in different regions of Russia, representing advertising material and signboards where different languages and cultures meet. Methodologically, the photos were classified and analyzed according to the types of code-switching and hybrid structures appearing in and on them. Some history is given on the cities studied, as well as the state of the languages that are part of their linguistic repertory. A few particular situations are scrutinized, involving national republics and other areas where linguistic minorities exist (major cities, provinces, villages). A strong tendency for the use of foreign culture was evident in the findings all over the country; the English language was preferred, but not perfect; an Asian influence was emerging everywhere. Wordplay characterized the creative employment of letters and words. Yet the cultures of the former Soviet Union, as well as the cultures of linguistic minorities (other languages besides Russian) were underrepresented, even in the national republics. The conclusion is that the modern language of the street is oriented towards the fusion of diverse cultures, but not necessarily those that represent the ethnic and cultural richness of Russia. Multiculturalism as reflected in public signage is more lively than multicultural policy because of emotionality and linkages with styles and scripts.
\end{abstract}

Ke ywords: Russian linguistic landscape; multilingualism; multiculturalism; hybrid culture on signs; visual linguistic diversity.

\section{ИНТЕРКУЛЬТУРНОСТЬ В СОВРЕМЕННОМ РОССИЙСКОМ ЛИНГВИСТИЧЕСКОМ ЛАНДШАФТЕ}

\author{
Протасова Е. Ю. \\ Хельсинкский университет (Хельсинки, Финляндия) \\ ORCID ID: https://orcid.org/0000-0002-8271-4909
}

\begin{abstract}
А н н о $\mathrm{m}$ a u и я. Цель данной статьи состоит в том, чтобы дать краткий обзор межкультурных тенденций в современных лингвистических ландшафтах некоторых регионов России. Поднимаются и решаются вопросы о том, где их можно найти, почему используются языки, отличные от русского, какова цель их использования и кто их применяет. Статья опирается на фактический материал, представляющий собой собрание из нескольких тысяч фотографий, сделанных в период с 2010 по 2018 гг. в различных регионах России. Коллекция включает в себя изображения рекламы и вывесок, в которых встречаются различные языки и можно обнаружить признаки разных культур. С методологической точки зрения фотографии были классифицированы и проанализированы в соответствии с типами переключения языкового кода и гибридными структурами, которые в них появляются. Приводится краткая история изучаемых городов, а также сведения о состоянии языков, входящих в их лингвистический репертуар. Изучается несколько конкретных ситуаций, связанных с национальными республиками и другими районами, где существуют языковые меньшинства (крупные города, провинция, деревни). Очевидна сильная тенденция к использованию иностранной культуры в изучаемых изображениях, собранных по всей стране; в них предпочитается английский язык, но он не совершенный; повсюду проявляется влияние азиатских культур. Языковая игра отражается в творческом применении букв и слов. Однако культуры бывшего Советского Союза и культуры языковых меньшинств (с языками, отличающимися от русского) представлены мало, даже в национальных республиках. В итоге современный язык улицы ориентирован на слияние различных культур, но необязательно тех, которые представляют этническое и культурное богатство России. Различ-
\end{abstract}


ные знаки и вывески, находящиеся в общественном пространстве, намного ярче представляют многосторонность языков и культур, чем могло бы показаться на основании политики поликультурности, благодаря эмоциональности и разнообразию используемых шрифтов.

Ключев ые слова: российский лингвистический ландшафт; многоязычие; многокультурность; гибридная культура на знаках; визуальное языковое разнообразие.

Для иитирования: Протасова, Е. Ю. Интеркультурность в современном российском лингвистическом ландшафте / Е. Ю. Протасова. - Текст : непосредственный // Филологический класс. 2021. - T. 26, No 2. - C. 52-67. - DOI: 10.51762/1FK2021-26-02-04.

\section{Introduction}

Without a doubt, all modern urban landscapes are multicultural [Itagi, Kumar Singh 2002; Backhaus 2007; Dufva, Pietikäinen 2009; Rozina 2007]. This bias has been the focus of attention since the first publications in the field [Landry, Bourhis 1997; Tafoya 2002; Cenoz, Gorter 2006; Gorter 2006; Shohamy, Gorter 2008; Shohamy, Ben-Rafael 2010]. In Russia, not all languages enjoy the same prevalence as Russian, which is the state language. In the educational system, it coexists with foreign languages and, depending on the region, with many indigenous minority languages. There are also a number of immigrant languages, mostly the languages of the former USSR republics, China and Vietnam [Chudinovskikh, Denisenko 2017]. As a consequence, the linguistic landscape (LL) has become a crossover of official language policy for visual signs in the public space, on the one hand, and people's images of a normal or better life as reflected in advertisements, on the other.

In the national republics (administrative units with 38 other co-official languages), an intentional intervention into the landscape may help add regional colour to the scenery. In some other national and non-national territories, the introduction of minority languages into the urban landscape still seems odd. Some wary citizens occasionally experience it as a violation of the rights of the omnipotent Russian language. At the same time, language revival activists take pleasure in producing postcards and advertisements for general purposes in their own language. This commotion promotes familiarity with the minority languages, which tend to lack visibility in the public sphere [Zamyatin et al. 2012].

Being almost isolated from the Roman alphabet in the public sphere for many decades, Russia
For citation: Protassova, E. Yu. (2021). Interculturality in the Modern Russian Linguistic Landscape. In Philological Class. Vol. 26. No. 2, pp. 52-67. DOI: 10.51762/1FK-2021-26-02-04.

enjoys playing with Western values and Westernized identifications [Mustajoki, Protassova 2012], while searching at the same time for its own roots. It is not surprising that freedom is associated with the deliberate use of letters. The intersection of Russian and the international English language is predominant in big cities, whereas, conceivably, minority languages are underrepresented, which is often the case elsewhere in the world [Edelman 2014; Mirvahedi 2016; Rasinger 2014]. I spotted the same tendencies in many major cities in Russia, although the countryside remains almost beyond the reach of foreign influences. The attitudes of the representatives of various layers of civil society are grounded in cultural preferences; self-identification on the axes of 'one's own' vs. 'the other', or East vs. West, or authoritarianism vs. democracy, or sympathy vs. opposition to the powers that be depends on collective and individual experiences, not ignoring emotions [Mustajoki, Protassova 2012]. In parallel, ethnic mobilization plays an important role in the national regions [Lallukka 1990; Funk, Sillanpää 1999; Kutlay, Kroon 2003; Protasova 2015], and one of the signs of this reclaiming of public places can be seen in the new ways in which people use languages, their emotions and visual interpretations [Grishaeva 2015]. The LL in Russia has rarely been studied, while Russian has established itself as an integral part of the LL in the Near and Far Abroad [Kreslins 2003; Litvinskaya 2010; Pavlenko 2012; Protasova 2013; Yelenevskaya, Fialkova 2017].

At the same time, linguistic issues and even orthographic rules can interact with ideologies. Let us take an example. In 1999, Tatarstan decided to Romanize the script (the first attempt dates back to 1928-1939), but in 2004, it was again classified as unconstitutional to violate the law and 
try to use an alphabet other than Cyrillic for most of the languages in Russia [Sebba 2006]. The dispute between supporters and detractors of the Roman script is not as painful as elsewhere, for example in Serbia and Kazakhstan [Ivković 2013; Kazakhstan 2017]; nevertheless, the use of a different alphabet for the same language is loaded with meanings. The public discussion goes beyond the distinction between professionals and amateurs and sometimes leads to highly dangerous and morbid aggravations. In the LL, the Tatar inscriptions may appear in Roman script if they are transliterations of the names given to public places. In this way, the LL meddles in linguistic ideologies and represents the real interests of language activists with regard to what must be said overtly, and how.

The language policy is not necessarily effective because broader economic and political forces are in play. With globalization, the influence of English as a lingua franca is evident everywhere worldwide [Wright 2004]. Via the commodification theory, Pavlenko [2009] suggests that after the dissolution of the USSR in 1991, Russian was rapidly replaced by English in secondary and higher education throughout most of the former Soviet republics and the so-called socialist countries. Yet during the 2000s, the status of Russian changed all over the world as a result of Russia's new economics and a major immigration wave [Yelenevskaya, Protassova 2015]. It re-established itself in some CIS countries as the language of the diaspora and the language of prestigious merchandise. For example, in Tadzhikistan, people still have quite a number of objects bearing a full inscription in Russian, or traces of the Russian language [Khudoikulova 2015]. Again, Russian later became popular as a means of managing the needs of the growing numbers of Russian speakers abroad [Muth 2017]. It is evident therefore that the LL should be studied diachronically [Moriarty 2014; Pavlenko, Mullen 2015].

In the nation itself, the constellation of languages is changing, as internal and external migration influences demographics and the ethnic composition [Chudnovskih 2011]. Some languages may be studied in detail, such as Italian in Moscow [Perotto 2015]. For many older residents, the use of non-academically acquired Russian as a second language by newcomers in traditional Russian-only constellations is shocking, as they consider that immigrants should learn Russian perfectly before coming to Russia, and they have little experience of listening to Russian as spoken by learners [Petrova 2017]. Yet, in its written form, this immigrant Russian seems to be more typical of marketplaces, public transport, and self-made announcements attached to trees or noticeboards, rather than being found in more official places, as illustrated in Figure 1.

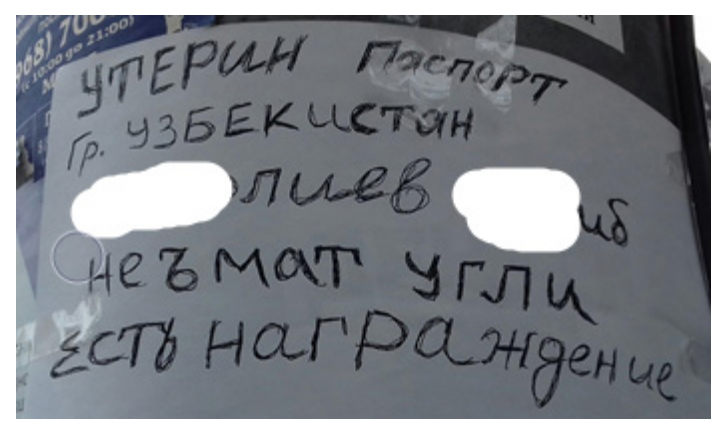

Figure 1. Announcement about a lost passport placed on a lamppost by a citizen of Uzbekistan in Moscow. Photo by Dmitry Sitchinava

Brand names are an important aspect of LL studies [Tufi, Blackwood 2010]; for Russians, they are an important symbol of belonging to the global mainstream. This added value sometimes leads to misuse and naivety, however. Aronin and Singleton [2012: 168-174] point out that in a modern society, material culture in itself is a specific blend of materialities. They can be bought, imprinted, worn, handwritten, and so forth. They might be part of a calculated design and impression, or spontaneous and occasional.

In this article, the LL is understood as a metaphor for the modern sociolinguistic situation in Russia, as an instrument for embracing globalization and diversity ("to be like everyone else and still different"), as a way of expressing pride in the semiotic diversity allowed in society, as well as delight in participation in a cultural clash understood as one modern tendency among others. Since Perestroika, Russia has been characterized as more open towards the world, as a result of which changes have occurred in people's attitudes towards previously forbidden Western values, along with the ethnic rise in and mobilization of local linguistic minorities and the influx 
of immigrants. This has also ushered advertising into the linguistic landscape of the country. The contemporary Russian LL, influenced to some extent, just like everywhere else, by global design and ideology, is searching for its own specificity. In this vein, local languages and cultures might prove to be a valuable resource.

The goal of this article is to provide a brief overview of the intercultural tendencies in the modern LL of certain Russian regions: where it can be detected, why languages other than Russian are used, what the purpose of their use is, and who uses them. This interculturality might seem superficial, but it is nevertheless significant because citizens encounter it in their everyday lives. To this end, the research questions the article addresses are: What are the main tendencies in the Russian urban LL? How is linguistic diversity represented in public spaces? How do different languages intersect there? Does language planning affect the actual practices of citizens in large cities and in the provinces? Do the national republics within Russia differ from the multicultural cities when it comes to public language use?

I will provide some background information about the cities investigated and the situation of the languages that form part of their linguistic repertoire. I will also discuss several specific cases concerning national republics and other places with a linguistic minority presence.

The study was carried out in 2010-2019 during multiple trips to different parts of Russia. As this is a relatively long period of time, specifying when the fieldwork was carried out in each geographical location would have taken up too much time and space, and hence I have omitted this information. In Moscow, the LLs were photographed and analyzed extensively (all of the facades and advertisements in a street section) and frequently (twice a year); in some cases, shots of a whole street were taken and compared, producing a longitudinal study of sorts. In the case of other areas (Siberian cities, Finno-Ugric regions, small towns), visits were more limited in time. In the course of the investigation, several thousand photographs were taken. They were sorted and classified according to a number of specific criteria (the languages used, transliteration types, material objects, type of font, and so on). In the section that follows, I will firstly discuss some trends in the LLs as observed in different parts of big cities. Secondly, I will try to analyze the use of different alphabets and fonts as a mark of an author's vision of the commodities. Thirdly, I will visit the countryside (in almost each location I studied, I travelled for about 100 or more kilometres outside big cities) in search of multicultural phenomena. Fourthly, I will turn my attention to the national republics and compare their LL to that of the rest of Russia.

\section{Language legislation in Russia}

Russia is a multilingual state, proclaiming the importance of polyethnicism in the very first lines of its Constitution: "We, the multinational people of the Russian Federation, united by a common fate on our land...". According to the Constitution, Russian is the state language across the whole territory of the country.

The Federal Law of the Russian Federation No. 53 "On the State Language of the Russian Federation", published on 7 June 2005 , states that this language must be used on all official occasions, for example when geographical names or road signs are written. In official circumstances and in the national, regional, and municipal media, only the normative language can be accepted, and the norms are defined by the government; foreign words can only be used when no widely current equivalent exists in the Russian language. Official texts written in other languages alongside Russian should be identical in content and technical appearance to the original Russian text. These regulations do not affect trademarks, logotypes, or products designed for teaching languages.

The Law of the Russian Federation No. 1807-I "On the languages of the peoples of the Russian Federation", published on 25 October 1991, proclaims that languages are national property defended by the state. This concerns only the public sphere of language use. All languages of the Russian Federation (RF) are equal, all peoples and individuals can maintain and comprehensively develop their mother tongues, as well as freely choose and use the language of communication, education, instruction, and creation independently of their origin, social and property status, racial and national identity, gender, education, religion, or place of residence. National and regional media can use Russian or other languages; film productions can be translated into other languages according to the interests of the 
population. The use of different languages follows similar principles in the industrial, communication, transport, and energy sectors.

The Federal Law "On advertising" (No. 38) from 13 March 2006 prohibits the use of abusive words, obscene and indecent images, comparisons, and expressions, including those pertaining to gender, race, nationality, profession, social category, age, the language of a person and a citizen, official state symbols, religious symbols, and objects of cultural heritage of the peoples of the $\mathrm{RF}$ and of humankind.

The national languages in Russia use special characters that differ from the Russian Cyrillic, whereas Karelian and Finnish use Roman script.

\section{In the "Russian" Russia}

A comparison of scripts gives the following results. The Russian language has 33 letters, whereas the Roman alphabet usually has 26 . Some letters have the same shape but represent different sounds, as is the case with $\mathrm{A}, \mathrm{E}, \mathrm{K}^{*}$, $\mathrm{M}^{*}, \mathrm{O}, \mathrm{T}^{*}$ (" signifies those cases where the lower-case letter differs in shape). Others have the same shape but different sounds, like B (B), and C (Ц), where the Russian analogue does not exist in the Roman script. Some have similarities in certain fonts and/or sizes, but differ in others, like $\mathrm{D}($ (Д), and $\mathrm{Y}(\mathrm{Y})$. Some have a similar shape, but represent different sounds, like H / X [Rus. h] / $\mathrm{N} / \mathrm{H}$ [Rus. n], and P / $\Pi$ [Rus. p] - R / P [Rus. r] (the Russian analogue exists in the Roman script but is pronounced differently). Some sounds are represented by completely different shapes, like $\mathrm{F}$ (Ф), G (Г), I (И), J (Й), L (Л), S (C), U (У), and V (B). Certain letters are peculiar to the Roman script, such as W, and Z; others are peculiar to Russian, such as Ё [jo], Ж [zh], 3 [z], Ц [c], Ч [ch], Ш [sh], щ [shch], b [hard sign], b [y], b [soft sign], Э [è], $Ю[j u]$, and $Я[j a]$. Others are misleading, like R / G, N / U, E / $\ni$ because they are almost a symmetrical reflection. Some small handwritten Roman letters may sometimes be confused with other Russian letters (like $b$ and в, $g$ and $\mathrm{g}, r$ and $r, y$ and $y, p$ and $\mathrm{p}, u$ and $и, n$ and $\Pi$, and $m$ and $\mathrm{T}$ ).

One of the most renowned contemporary Russian writers, Boris Akunin [2011a, b, 2012], has mirrored the use of the scripts in the titles given to a series of novels by Anna Borisova, his female pseudonym. One is called "Vremena goda" - two Russian words written in Roman letters. Another has the name "TAM..."; if capitalized, the Cyrillic and Roman letters coincide; in handwriting, the Russian $\mathrm{T}$ and the Roman $\mathrm{M}$ are the same, while a small Roman $\mathrm{T}$ and a small Russian $\mathrm{M}$ are different. The third title has an international stem creativ- and a very typical Russian suffix -shtshik. Thus, the visualization reflecting the Russification of Western concepts or the Westernization of Russian ideas is taking place even in fiction.

An analogous script game is proposed by another famous writer, Sergei Minaev. The titles of his works include "Дyхless. Повесть о ненастоящем человеке" [2006], "Media Sapiens. Повесть о третьем сроке" [2007], "Тhe Тёлки. Повесть о ненастоящей любви" [2008], and "Videoты" [2010]. The interplay between large and small, Cyrillic and Roman letters, the addition of articles (non-existent in Russian) and suffixes, Westernized and Russified versions, and the complexity of understanding where one language ends and the other begins are typical of other writers' style as well.

Hybrid formulations are perhaps the wittiest instances of creativity: www.biGOODi.ru (capilliculture, named after hair rollers bigudi, pronounced like be-goody); love of shoes becomes shuzofilija according to Russian composite word formation; SeaZone Отдыхай 'relax' (season is pronounced as sizon in Russian); Vippechka (VIP+печка 'stove'= выпечка 'pastry'). The name of the shop проBEERка combines Cyrillic and Roman; it can be read in different ways, like Rus. проВЕРка 'inspection' or проБИРка 'capsule', or the hybrid pro-BEER-ka 'about beer something; one should supposedly drink beer in the café ВеerЛОГА 'den'. On the sign DOM MOD ('house of fashions' should be ДОМ МОД in Cyrillic), the anagram communicates the notion that fashion trends are globally acknowledged. Sometimes only one or two letters mark a Western touch to the Eastern world: BAZAP should be BA3AP 'bazaar', especially in combination with the adjective модный 'fashionable'; Dжекиt from 'jacket' and Sтэйси 'Stacy' in a pseudo-Russian half-transcription are the names of clothing stores. Words like classic, extra, and super are beloved by marketeers. Sëstry Mamutiny Салон трикотажного платья (designers' brand); ПИЦКИ (manicure \& pedicure); Грэнни'с (cafeteria; non-typical of the Russian language, an apostrophe is used); Лакшери STORE ZILLI; DOSTAEBCКИЙ ВOT 
TAK WОK!; REAКТИВ (shooting gallery); Bon Аppart МИНИ - ОТЕЛЬ (small hotel, allusion to Bonaparte); www.RODINASTORE.ru (this is the name of a real store, not of the website; presumably, you do not write 'motherland' in Roman script); Blackwood Nevvod space; BERËZKABAR (cocktails \& friends, an allusion to the Russian and Soviet past); Matryoshka; Killfish - Discount BarКиллфиш (in English); Ресторан Boulangerie кафе, La Famille свадебный салон 'wedding office' (in French); Te Amo (beauty studio); Trattoria (in Italian); Русский KAMMAY; one-word terms like LOOK, HOUSE; NEVESTA 'bride' (wedding and party fashion); For MEN (men's clothing); Dance club OSOBNIAK event hall 'mansion'; and Halli Galli (bars with dances) are further examples of script combinations.

There are international trademarks like $E x$ Treme знает, что ты хочешь by Nestle, Nikko Dry Cleaners химчистка экспресс. The international brands may be transliterated, translated, invented, reproduced, or recombined in the Russian language (Молли Гвиннз Паб at 24 Pyatnickaya street, and Эстелла Джувелери at 25 Руatnickaya in Moscow; transliterated forms include Рив Гош (Rive Gauche), Л’Этуаль (L'Étoile), Райффайзенбанк (Raiffeisenbank), К-Раута (K-Rauta), but L'Occitane en Provence, Wittchen, BeFree, Calvin Klein, Chester, Henderson, and Prisma retain the Roman script. Some advertisements seem to be international, but nobody knows whether they really are; examples include Астери Талассо (Asteri Talasso), СИТИ (City), Айсберри (Iceberry). The incorrect Chokkolatta should be Cioccolato/- $a$ in Italian; it is the name of a "café мансарда" (café written in Roman script, 'mansard' in Russian). The Russian word Shkatulka 'ornated box', Babochka 'butterfly', moloko 'milk' (the name of a beauty salon), and KLEVO! 'cool' are written in Roman script. Some may derive from Chinese (Фалунь фафа система сохранения души и тела). After transliteration, the prefixoid Euro- usually becomes evro-. Another example is AYTLETO, where the English part out is in Cyrillic transliteration, and the Russian part leto 'summer' is in Roman script; as a result, the summer sale alludes to an outlet. Cheeseburgers are sold in \#FARU $W_{s}$ a combination of Roman and Cyrillic that should mean 'minced meat'. There are also ХИщNІК Стейкс \& Burgers (half-Russian and half-English), and the GOOD BAR, which trans- literates DANCE \& GRILL as ДЭНС \& ГРИЛЬ. The MASOET Meat Company (myasoet.ru) includes restaurants with Turkish cuisine; the name plays with Cyrillic and Roman letters and combines the words 'meat' in Russian and Turkish; when pronounced, it sounds like the Russian word 'meat-eater' (in the written form, it could indicate a mistake). The name of the chain ШашлыкоFF continues the line where the nominals refer to Russian family names abroad. The names of visiting musical groups remain unchanged (Figs. 2, 3).

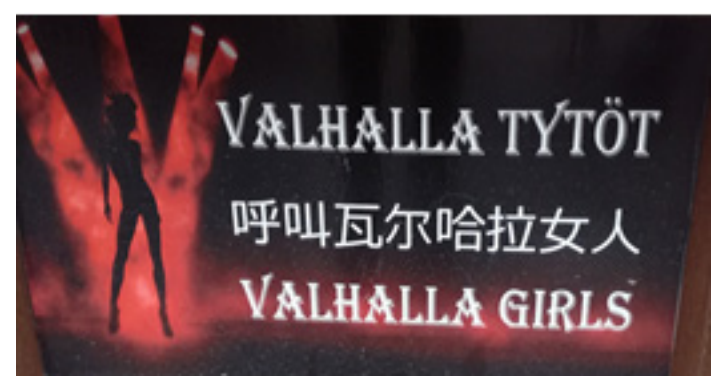

Figure 2. In St. Petersburg, one inscription was in Finnish, Chinese and English without any Russian. This could indicate that the information is intended for foreigners only and that the most common tourist groups speak these languages.

Photo by the author

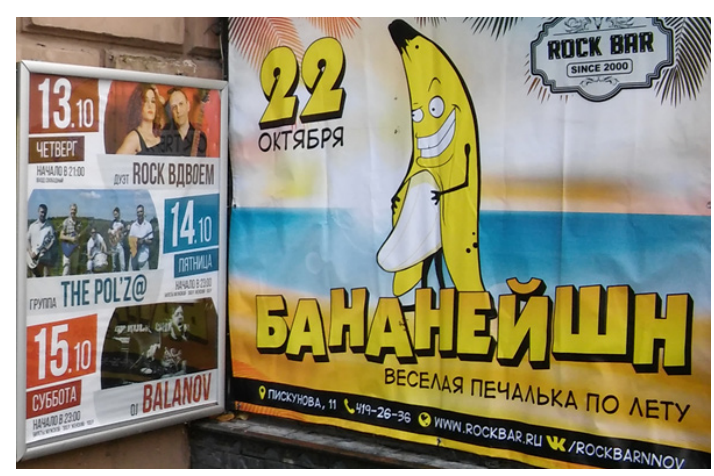

Figure 3. Different tendencies in a bar advertisement in Nizhny Novgorod: Rock Bar

Since 2000; Rock вдвоем; THEPOL'Z@; BALANOV; Бананейшн Веселая печалька по лету. A bananeishn, or bananation, is a party where people are dressed and behave in a summery manner. Photo by the author

There is a script called ustav (often referred to as Slavic vjaz', which is incorrect historically; see Fig. 4) that may correspond to the concept of 
Gothic script for the Roman alphabet. Basically, it is used to signify something typically Russian or ancient but, paradoxically, other minority languages also use it in this way. The names of restaurants, cafés, souvenir shops and sacred places are among those written in ustav (е.g., Сибирская трапеза, Монастырская трапеза, Русская трапеза, Аппетитно Вкусно Быстро, Домашние обеды). Some inscriptions appear with $\mathrm{a} \mathrm{b}$ at the end (not used in this sense in modern Russian, as well as the less frequent $\mathrm{b}$ ), which is not allowed in the current orthography and mirrors the old style, like "Кофейная ресторация Ландринъ". The orthography is inconsistent in this respect.

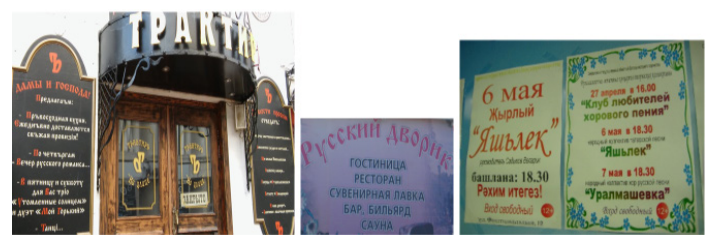

Figure 4. Examples from Nizhni Novgorod (left), Cherepovec (centre) and Ekaterinburg (right). Photos by the author

In large cities in Siberia, some local influences from dialects and minority languages can be spotted, including shurushki 'small things, details', mineral water Chazhemto - 'frog swamp' in the Selkup language, the fish peljad' in Irkutsk, and the pie xushur (from Buryat culinary tradition) in Irkutsk. The script may be adapted to represent ethnic (Vietnamese, Indian, Japanese, Korean, Eastern etc.) cuisine. In Ekaterinburg, I also came across announcements in Tatar.

\section{In the national regions}

All national regions have their own history of literacy and understanding of the importance of displaying their ethnic and linguistic diversity in the public sphere. The situation in Chuvashia was aptly analyzed by Alos i Font [2019], who meticulously scrutinized the LL of the republic's capital and established how it depends on the actual political situation and activists' movements. Protassova and Shchemerova [2014] documented the LL in several national regions. The emphasis was on Mordovia, where national folklore plays a role in the recent naming of public services, and Buryatia, where national dishes are prominent on the signboards. They also demonstrated how the LL is manifested in Yoshkar-Ola, the capital of the Mari El Republic, which is located on the River Volga at a distance of 8,000 kilometres from Moscow. The population of the city is less than one million, and about $42,9 \%$ are Mari; about half of all Mari live outside this territory. The Mari language and its dialects are visible in the names of state institutions and administrative units, on street signs and other public signs, as well as on stamps. The Law "On the Languages in the Mari El Republic" [1995] declares that Mountain (Hill) and Meadow Mari, as well as Russian languages are state languages in the Republic. Inscriptions in the Mari language can be observed in a preschool where Mari is taught intensively, in an archive, in a concert announcement, on street signs, and in a shop. Some information appears in both Russian and Mari, while some is partly translated.

Other examples include the following. The Sakha (Yakutia) Republic covers an enormous territory $\left(3,083,523 \mathrm{~km}^{2}\right)$ in Eastern Siberia, but has fewer than one million inhabitants. Ethnic Yakuts comprise about half the population; more than $60 \%$ of all inhabitants speak Sakha (Yakut) (which is a Turkic language with Mongolian, Paleo-Siberian, Russian and other influences). There are indigenous minorities here - Dolgan, Evenki, Even, Yukaghir, and Chukchi. The region is very special from the point of view of the traditional cultural heritage, and is rich in natural resources such as diamonds, gold, tin mines, mammoth bones, and exceptional horses and cattle.

The Law on Languages in the Sakha Republic (Yakutia) (1992, and later amended) declares two official languages, Russian and Sakha (Yakut), and also provides means for the use of local languages in compact settlements. According to this document, the Republic of Sakha (Yakutia) resolves issues in the field of legislation on the development and use of languages on its territory, taking into account the interests of the peoples living there. It recognizes the inalienable right of citizens of any nationality to the free development of their native language and culture, and the equality of all citizens before the law, regardless of their native language. The law underlines the need for improving the teaching and learning of native and foreign languages [Robbek 1998; Badmatsyrenova, Elivanova 2008]. It appears that the law has largely been implement- 
ed accordingly ${ }^{1}$. Among the hunting and fishing equipment stores, Байанай (Baianai is the spirit of forests and animals in Yakut mythology, and the patron saint of hunters], Бэргэн (Bergen, a name meaning 'right on target') and Булчут (Bulchut, 'hunter') have Yakut names. In the pictures, Bibelots is French (the translation is incorrect, as it is 'gifts' in Russian), Кружало (Kruzhalo, which has different meanings, e.g., 'potter's wheel') market is written as ustav in Russian. The words 'fruit and vegetables' appear in Russian and Yakut (additional inscriptions in Russian), administrative signboards are in two languages, traditional souvenirs are named in Yakut, or Yakut, Russian and English, and advertisements for the National Theatre are mostly in Yakut (see Fig. 5). This distribution of languages shows that the title language is used in specific domains as a marker of the local culture and legislation, but at the same time, other languages are welcome. For example, French, the language of northern neighbour Canada, is taught in many schools alongside English.

The Udmurt Republic is a sovereign republic within the Russian Federation, with a population of 1,5 million. There are about 750,000 Udmurt people altogether, most of whom live in the republic, while others reside in other regions in Russia. The Udmurt Republic is situated in the Western part of the Middle Urals between the Kama and Vyatka Rivers. Izhevsk, the capital of the Udmurtia Republic, is located at a distance of 1,325 kilometres from Moscow. Russian and Udmurt (a Finno-Ugric language) are both state languages in Udmurtia; about 100 other languages are also spoken. There is a Ministry of National Affairs that takes care of the presence of the language in the public sphere [Salánki 2007]. The Law of the Udmurt Republic "On the state languages of the Udmurt Republic and the other languages of the peoples of the Udmurt Republic" [2002] considers this indigenous language endangered despite the number of people speaking it, because fewer and fewer Udmurts report it as their mother tongue [Khakimov, Trusova 2010]. The administration has tried to introduce public signs in the two languages, translations of official documentation, and new words to be adopted into the language. The photographs illustrate how the two languages are placed on the same sign plate or on two plates near each other (there may also be two signs on either side of the entrance); not all of the information is duplicated. The Udmurt precedes the Russian or vice versa. Numerous shops and public transport stations have signs in two languages; unfortunately, we have no statistical information on this (see Fig. 6). In effect, difficulties are experienced when trying to apply bilingualism in practice in the public sphere [Torokhova 2012].
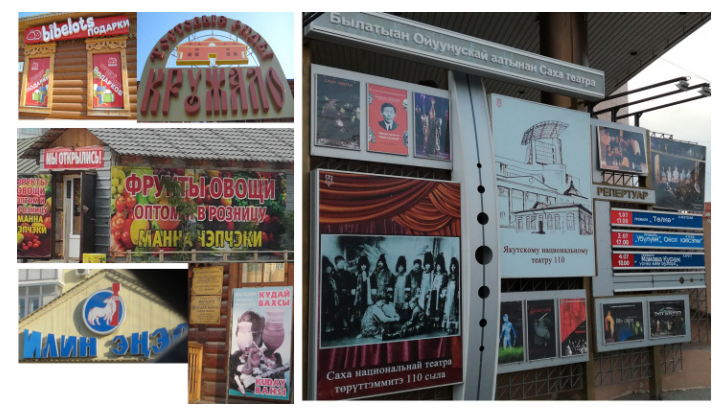

Figure 5. The LL of Yakutsk: some French, some Russian Ustav, and the national Yakut language. Photos by the author
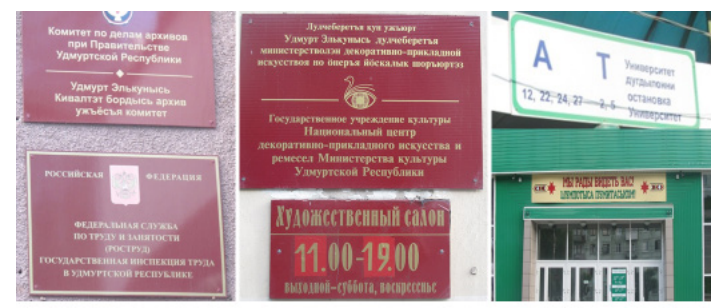

Figure 6. The linguistic landscape in Izhevsk. Photos by Eduard Khakimov

In Kudymkar (in the Komi-Permyak region), signs in the national language are connected with cultural events, teaching the language, and official organizations (like ministries, museums, concert halls, theatres, restaurants, and teachers' forums). Most of the inscriptions are in Russian only (see Fig. 7).
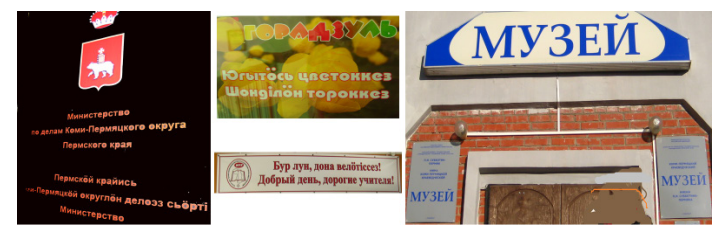

Figure 7. The linguistic landscape of Kudymkar. Photos by the author 
The Republic of Karelia in Northwest Russia is home to many Karelians (about 10\% of the population), totalling about 125,000 altogether (other Karelians live in Finland and in the Tver and Leningrad regions). Four languages are important in this province: alongside Karelian and Russian, the Finnish and Veps languages are used. Karelian has to be written in Roman letters, as does Finnish, but this decision came about only recently. Proficiency in Karelian and Veps is low [Toivanen, Saarikivi 2016]. Finnish is mostly taught as a foreign language, although there are still Finns living in Russia. There is no language law, but relevant legislation includes a Law on Education (1994), a Law on Culture (1995), and a Law on State Support for the Karelian, Veps, and Finnish Languages in the Republic of Karelia (2004) [Klementyev et al. 2012]. Signs in Finnish may be addressed to locals as well as to Finnish tourists. One shopping centre is called Onnela ('place of luck', 'Paradise', 'Eden') in some Karelian dialects as well as in Finnish. According to an interview conducted by Karelian activist Natalia Antonova, the owner of the centre, who is an immigrant from a former Soviet republic himself, wanted to have a name that would reflect local colour, and asked her to suggest one. Today, he is starting a new project, and again wants to adopt a Karelian name for it. Language activists have actually founded a House (home) for the revitalization of the Karelian language in the Vieljärvi commune (Fig. 8).

The capital city of Petrozavodsk was founded in 1703 by Peter the Great for military needs. The population of Petrozavodsk is predominantly Russian (87\%). Karelians make up about $4 \%$, Veps about $1 \%$, and Finns about $2 \%$ of the population in the city. There is greater interest in learning Finnish than Karelian or Veps. Signs in Finnish are more prevalent than other non-Russian inscriptions. The National Theatre uses four languages in advertisements (Russian and Finnish predominate, sometimes playing with Cyrillic and Roman letters) and provides simultaneous translation during the shows (for reference, see n-teatr.ru).

The national languages are not present everywhere. In Altay, for example, the salience of the local Altay language is not noticeable (Fig. 8 is an exception and is for the attention of tourists). In some settings (see Fig. 9), local languages are a charming exoticism. The German language can be seen here and there in the national region of Russian Germans around the Siberian city of Omsk (Fig. 10). In many national territories, there is either no sign of local languages, or they are underrepresented (see Fig. 11).

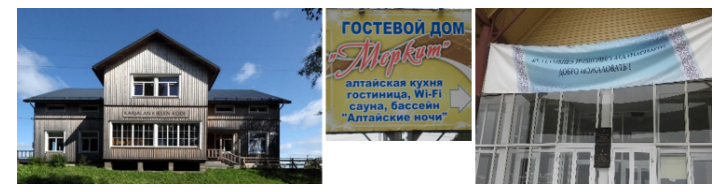

Figure 8. The House (home) of Karelian language in Vieljärvi (Karelia). The inscription is in Karelian. Photo by Natalia Antonova. In Altay, the only inscription with local colour concerned the naming of the hotel in a village. In Nanai Sikachi-Alyan village, situated on the bank of the Amur River in the Khabarovsk region, the welcome banner on the administrative building is in Nanai and Russian. Photo by the author

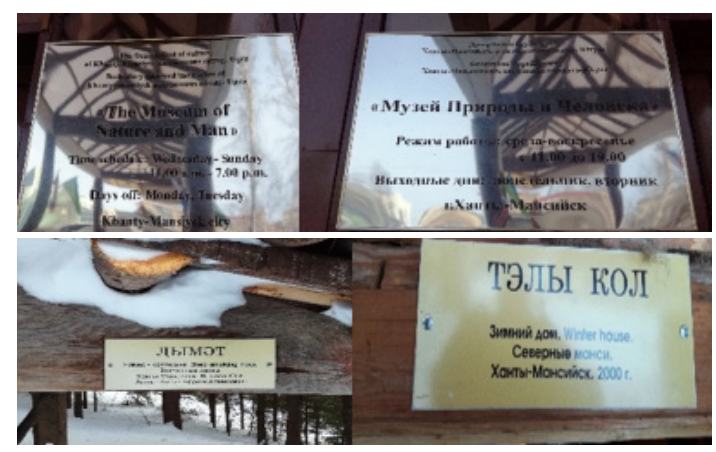

Figure 9. In Khanty-Mansijsk, the modern museum has inscriptions in Russian and English only. Words in the local languages can be found in the ethnographic park. Photos by the author

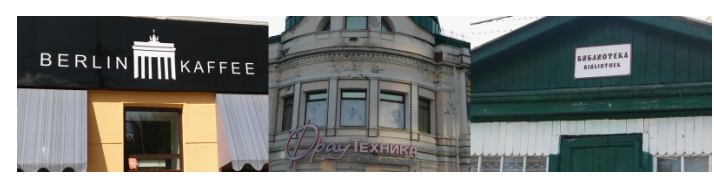

Figure 10. Omsk and Alexandrovka. Photos by the author

Tatarstan is located on the Volga and is a flourishing self-confident republic of Russia, preserving its national language and identity by all possible means, revitalizing Islam and Orthodoxy, and stimulating international relationships in science, education, and the econ- 
omy all over the world. The distance between Moscow and Kazan is about 825 kilometres. According to the Law "On the Languages of Peoples of the Tatarstan Republic" (1992), both languages, Tatar (Turkic) and Russian, have the status of state languages and enjoy equal rights; still, only about $50 \%$ of Tatars (about 3.7 million) can speak the local language fluently [Graney 2010]. Rychkov and Rychkova [2012] have studied ethnolinguistically loaded landscapes of the capital, where similar information is provided in Russian, Tatar, and English, or in a combination of all three. In addition, other languages may be used in the streets and in the mass media. Beyond the central streets, the LL is more like everywhere else in Russia, with the exception of a few inscriptions in the Tatar language and names of Tatar origin. In November 2018, in one of the main areas, Bauman pedestrian street in a segment about 1,000 steps long, about $60 \%$ of the advertisements and signs were in Russian, $30 \%$ in international English, and 10\% in Tatar (Fig. 12). Aristova [2016] also demonstrated that in the LL in Tatarstan English predominates over the local language, Tatar.

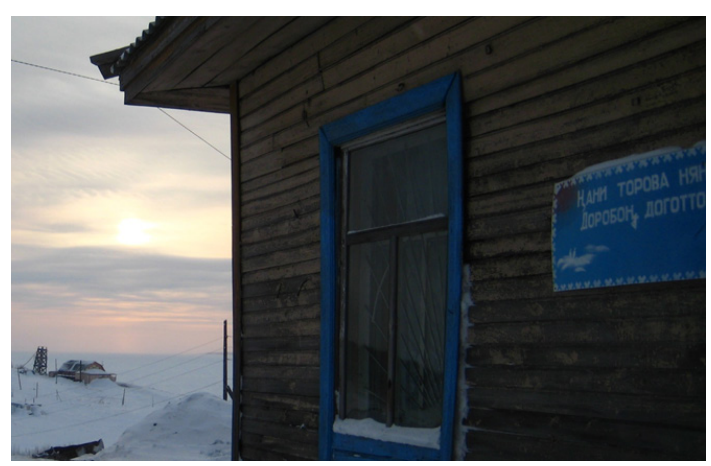

Figure 11. In the village of Potapovo on the Taymyr Peninsula, a non-Russian inscription appears in the Nenets language (on the side of the local shop).

Photo by the author

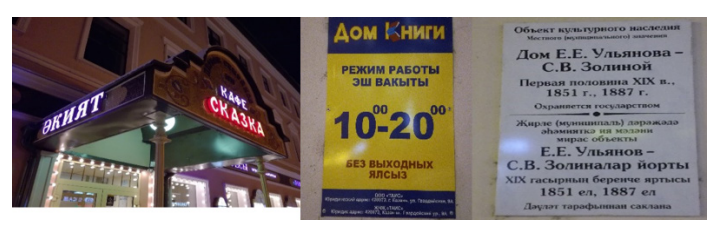

Figure 12. The Bauman pedestrian street in Kazan

\section{Discussion}

The language policy, as reflected in the laws, regulates some of the practices aimed at advertising and presenting languages in the public space. The other side of the issue concerns people's wishes to see their language as part of their scenery, to be served in the language, and to feel at home within family communication. This can be achieved through a linguistic landscape that welcomes local languages and realities. Through acquaintance with the 'big letters' on inscriptions, those who have doubts about their knowledge will acquire new words and use them more often than before. This will contribute to the maintenance of the national languages of Russia. Shortcomings sometimes occur due to a lack of specialists who could provide good translations on all occasions. Sometimes dialect speakers do not recognize 'their own' language in what they see and reject the idea of the written language. Conflicts occur between the norms known only by a few and a level of reasonable proficiency, especially because Russian and local tongues are constantly mixed. The practices of using languages in the public sphere are inconsistent, as is the case in other countries as well [Lado 2011]. Nevertheless, signs in the national languages were few and far between among the signs visible in the linguistically specific areas. As my interest lies in linguistic diversity, I was able to find them precisely because I was purposefully searching for them.

I found some traces of a regional touch everywhere, but 'Russian Russia' tendencies (the use of English and other foreign languages, reminders of the past) are evidently more important than local colour. Russian predominates everywhere. The villages do not produce many visual written symbols, preferring to use ready-made external signboards. National, minority, and global structures usually interact in the multi-layered LLs of minority villages; each logic is oriented towards a specific audience [Pietikäinen et al. 2011]. The new tendency, seen to varying degrees in the cities of the national republics and connected to the growing number of well-educated young professionals coming from the countryside and speaking their heritage languages, might introduce more wordplay into the signs in their towns. In this way, they have the potential to bring about a transformation in the LL. 


\section{Conclusions}

According to the Constitution of the Russian Federation, Russia is a multilingual and multicultural country. Although there are laws governing the use of language and advertisements in the public sphere, there is no official policy towards language use in LLs. In other words, nobody sees the urban landscape as an entity that must be looked after. Therefore, in reality, the LL does not represent a variety of ethnic cultures at all levels of the use of languages - everyday, cultural, historical, or official. This raises the question of whether the LL should orientate people towards the use of languages. Multicultural linguistic constellations in the streets often seem to take the form of a symbol or a joke, or play with the form and content of letters and words. Alongside official use in the national republics, all other inscriptions rely on the creativeness of the citizens, who reflect their preferences and dreams in them. Russian cities represent meeting points for global and local tendencies in LL development. Immigrant varieties of Russian can be seen in those places where they intersect. Activists are fighting for the presence of their own languages on the internet, which has become prestigious and polyfunctional [Orekhov, Reshetnikov 2016], and in many places, we can observe the same efforts being made in the LL. As Hämäläinen [2021] puts it, endangered languages are not low-resourced, and if the necessity and demand emerge, they can always enter the public space.

The inscriptions do not represent real proficiency in many languages, but play with various influences instead, mostly stemming from an imagined and constructed life abroad rather than from indigenous roots and cultures. Sidorova et al. [Sidorova et al. 2014] witnessed analogous issues in the north of Yakutia. It seems that multilingualism based on the knowledge of one's own languages is possible, but not truly supported, and allusions to foreign languages overwhelm. Clashes between Slavicisms, localisms, and globalisms in the spontaneous use of brand names in the urban space and in the provinces lead to the creation of a specific mixed culture. This culture sometimes uses the Roman script independently of the rules of any existing language, sometimes in accordance with a transliteration system. This constructed Westernness diminishes when one goes deeper into the countryside, but never disappears completely.

As in many places around the world, the state language dominates, mutilated international English has entered the original multicultural frame, and a moderate presence of other foreign and local minority languages can be observed [Coluzzi 2009]. When speakers switch from one language to another in a multilingual setting, it is a symbol of their multilingualism [Angermeyer 2005]; when they just use certain words or change the script while expressing other meanings, it is often symbolic of their attitude.

Chinese, which also has a widespread international presence, can be discovered in several places. Some time ago, immigrant sellers in the markets wrote their announcements themselves on pieces of cardboard, and interesting instances of the use of different languages could sometimes be observed. Nowadays, this process is more computerized, and more Russian-speaking sellers are hired. Native bilingual writings are rare. Baranova and Fedorova [2017] obtained similar results in the pursuit of a migrant presence in the LL.

Through emotionality and associations connected to styles and scripts, multiculturality as expressed in public signs is more vibrant than the multicultural policy, although not all authors and observers are aware of its potential. Advertisements are directly connected to the interests and self-expression of the owners. The linguistic landscape speaks volumes about how ordinary and better-off people would like to live, the kind of shopping habits they have, how they spend their free time, and so forth. The provenance of symbols can be ready-made and global, or home-made and local, but their employment is a tool for reasserting internationality and diversity when different ethnicities abound. Humour, mistakes and misinterpretations are duly a natural feature of using languages that have not been learned properly.

\section{Литература}

Акунин, Б. = Борисова, А. Времена года / Б. Акунин = А. Борисова. - М. : Астрель, 2011b. - 480 с.

Акунин, Б. = Борисова, А. Креативщик / Б. Акунин = А. Борисова. - М. : Астрель, 2012. - 315 с.

Акунин, Б. = Борисова, А. Там... / Б. Акунин = А. Борисова. - М. : Астрель, 2011а. -320 с. 
Баранова, В. В. (Не)видимость и (вне)находимость: трудовые мигранты и языковой ландшафт Санкт-Петербурга / В. В. Баранова, К. С. Федорова // Городские исследования и практики. - 2017. - Т. 2, № 1. - С. $103-121$.

Замятин, К. Как и зачем сохранять языки народов России? / К. Замятин, Я. Саарикиви, А. Пасанен. Vammala : POGA, 2012. - $181 \mathrm{c}$.

Казахстан. Переход на латиницу. - Текст : электронный // Sputniknews.kz. - 12.04.2017. - URL: ru.sputniknews. kz/trend/latinica_12042017/?mobile_return=yes\&_ga=2.100417622.932187546.1542144213-848727409.1542144213 (дата обращения: 28.05 .2021$)$.

Орехов, Б. Государственные языки России в Википедии: к вопросу о сетевой активности миноритарных языковых сообществ / Б. Орехов, К. Решетников // Настройка языка: управление коммуникациями на постсоветском пространстве / под ред. Е. Г. Лапиной-Кратасюк, О. В. Мороз, Е. Г. Ним. - М. : НЛО, 2016. - С. $263-281$.

Петрова, Н. Мигрант с натуры. Кто теперь едет работать в Россию / Н. Петрова. - Текст : электронный // Коммерсантъ. - 12.08.2017. - URL: kommersant.ru/doc/3380376?utm_campaign=push\&utm_source=kommersant (дата обращения: 28.05.2021).

Протасова, Е. Вариативность лингвистического ландшафта России / Е. Протасова // Экология языка и коммуникативная практика. - 2015. - №. 4. - С. 91-102.

Протасова, Е. Многоязычие в облике регионов России / Е. Протасова, Н. Щемерова // Современные модели развития культурных индустрий в регионах России / под ред. М. Л. Магидович. - М. ; СПб. : РГПУ им. А.И. Герцена, 2014. - С. 189-194.

Протасова, Е. Русский язык в туристическом ландшафте зарубежья / Е. Протасова // Русский язык за рубежом. - 2013. - No 5. - С. 53-61.

Розина, Р. И. Чужие и свои слова на московских улицах / Р. И. Розина // Земская Е. А., Каленчук М. Л. Язык в движении. К 70-летию Л. П. Крысина. - М. : Языки славянской культуры, 2007. - С. 491-505.

Сидорова, Л. А. Лингвистический ландшафт северного поселка как продукт культурных индустрий (на примере п. Черский Республики Саха (Якутия)) / Л. А. Сидорова, Г. Фергусов, Л. Валликиви // Современные модели развития культурных индустрий в регионах России / под ред. М. Л. Магидович. - М. ; СПб. : РГПУ им. А.И. Герцена, 2014. - С. 195-204.

Торохова, Е. А. Языковая политика в Удмуртской республике / Е. А. Торохова // Вестник Удмуртского университета. Серия история и филология. - 2012. - № 2. - С. 152-158.

Хакимов, Е. Р. Русский язык как лингва франка в республике Удмуртия / Е. Р. Хакимов, Е. Г. Трусова // Instrumentarium of Linguistics: Sociolinguistic Approaches to Non-Standard Russian / ed. by A. Mustajoki, E. Protassova, N. Vakhtin. - Helsinki : University of Helsinki, 2010. - C. 127-138.

Чудиновских, О. С. Статистическое обеспечение миграционной политики РФ. Миграционный барометр в Российской Федерации / О. С. Чудиновских. - М. : МАКС Пресс, 2011. - 44 с.

Alos i Font, H. Russian, Chuvash and English: Minority-language activism, tourism promotion and the evolution of municipal advertisements in Shupashkar/Cheboksary (2015-2018) / H. Alos i Font // Russian Language in the Multilingual World / ed. by A. Nikunlassi, E. Protassova. - Helsinki : University of Helsinki, 2019. - P. 68-86.

Angermeyer, P. S. Spelling Bilingualism: Script choice in Russian American classified ads and signage / P. S. Angermeyer // Language in Society. 2005. - Vol. 34, No 4. - P. 493-531.

Aristova, N. English Translations in the Urban Linguistic Landscape as a Marker of an Emerging Global City: The Case of Kazan, Russia / N. Aristova // Procedia - Social and Behavioral Sciences. - 2016. - No 231. - P. 216-222.

Aronin, L. Multilingualism / L. Aronin, D. Singleton. - Amsterdam : Benjamins, 2012. - $230 \mathrm{p}$.

Backhaus, P. Linguistic Landscapes: A Comparative Study of Urban Multilingualism in Tokyo / P. Backhaus. - Clevedon : Multilingual Matters, 2007. - 158 p.

Badmatsyrenova, D. Language policy in Russia: The case study of the Yakut language / D. Badmatsyrenova, A. Elivanova // The Northern Research Forum Secretariat. The Borderless North. - Akureyri : University of Akureyri Research Centre, 2008. - P. 215-218.

Bruyèl-Olmedo, A. English as a lingua franca in the linguistic landscape of the multilingual resort of S'Arenal in Mallorca / A. Bruyèl-Olmedo, M. Juan-Garau // International Journal of Multilingualism. - 2009. - Vol. 6, No 4. - P. 386-411. Cenoz, J. Linguistic Landscape and Minority Languages / J. Cenoz, D. Gorter // International Journal of Multilingualism. - 2006. - Vol. 3, № 1. - P. 67-80.

Chudinovskikh, O. Russia: A migration system with Soviet roots. Migration Policy Institute, Migration Information Source / O. Chudinovskikh, M. Denisenko. - 18.05.2017. - URL: migrationpolicy.org/article/russia-migration-system-soviet-roots (mode of access: 28.05.2021). - Text : electronic.

Coluzzi, P. The Italian linguistic landscape: the cases of Milan and Udine / P. Coluzzi // International Journal of Multilingualism. 2009. - Vol. 6, No 3. - P. 298-312.

Dufva, H. Moni-ilmeinen monikielisyys / H. Dufva, S. Pietikäinen // Puhe ja kieli. 2009. - Vol. 29, № 1. - P. 1-14.

Edelman, L. The presence of minority languages in linguistic landscapes in Amsterdam and Friesland (the Nether-

lands) / L. Edelman // International Journal of the Sociology of Language. - 2014. - No 228. - P. 7-28.

Gorter, D. Introduction: The study of the linguistic landscape as a new approach to multilingualism / D. Gorter //

International Journal of Multilingualism. - 2006. - Vol. 3, № 1. - P. 1-6.

Graney, K. E. Of Khans and Kremlins: Tatarstan and the Future of Ethno-Federalism in Russia / K. E. Graney. Plymouth : Lexington Books, 2010. - XII, 288 p.

Grishaeva, E. B. Linguistic landscape of the city of Krasnoyarsk / E. B. Grishaeva // Procedia - Social and Behavioral Sciences. - 2015. - No 200. - P. 210-214.

Hämäläinen, M. Endangered languages are not low resourced! / M. Hämäläinen // Multulingual Facilitation / ed. by M. Hämäläinen, N. Partanen, K. Alnajjar. - Helsinki : University of Helsinki, 2021. - P. 1-11. 
Ivković, D. Pragmatics meets ideology: Digraphia and non-standard orthographic practices in Serbian online news forums / D. Ivković // Journal of Language and Politics. - 2013. - Vol. 12, № 3. - P. 335-356.

Khudoikulova, N. Linguistic situation in Tajikistan: language use in public space / N. Khudoikulova // Russian Journal of Communication. - 2015. - Vol. 7, № 2. - P. 164-178.

Klementyev, Y. The Karelian language in Russia: An overview of a language in context / Y. Klementyev, S. Kovaleva, K. Zamyatin // Working Papers in European Language Diversity 12. - Mainz etc. : European Language Diversity for All (ELDIA), 2012. - $14 \mathrm{p}$.

Kreslins, J. Linguistic landscapes in the Baltic / J. Kreslins // Scandinavian Journal of History. - 2003. - Vol. 28, № 3-4. - P. 165-174.

Kutlay, Y. Ethnolinguistic vitality perceptions and language revitalization in Bashkortostan / Y. Kutlay, S. Kroon // Journal of Multilingual and Multicultural Development. - 2003. - Vol. 24, № 4. - P. 319-336.

Lado, B. Linguistic landscape as a reflection of the linguistic and ideological conflict in the Valencian Community /

B. Lado // International Journal of Multilingualism. - 2011. - Vol. 8, № 2. - P. 135-150.

Lallukka, S. The East Finnic minorities in the Soviet Union. An Appraisal of the Erosive Trends / S. Lallukka. Jyväskylä : Gummerus, 1990. - 344 p.

Landry, R. Linguistic landscape and ethnolinguistic vitality. An empirical study / R. Landry, R. Y. Bourhis // Journal of Language and Social Psychology. - 1997. - Vol. 16, № 1. - P. 23-49.

Linguistic Genocide or Superdiversity? New and Old Language Diversities / ed. by R. Toivanen, J. Saarikivi. - Bristol :

Multilingual Matters, 2016. $-362 \mathrm{p}$.

Linguistic Landscape: Expanding the Scenery / ed. by E. Shohamy, D. Gorter. - London : Routledge, 2008. - 392 p. Linguistic Landscaping in India, with Particular Reference to the New States / ed. by N. H. Itagi, S. Kumar Singh. Mysore : Central Institute of Indian Languages, 2002. - XII, 255 p.

Litvinskaya, A. A. Linguistic Landscape of "Little Russia by the Sea", a Multilingual Community in a Brooklyn Area of

New York City : A Ph.D. Thesis / Litvinskaya A. A. - Indiana University of Pennsylvania, 2010. - 186 p.

Minority Languages in the Linguistic Landscape / ed. by D. Gorter, H. F. Marten, L. Van Mensel. - New York : Palgrave Macmillan, 2012. - XII, $347 \mathrm{p}$.

Mirvahedi, S. H. Linguistic landscaping in Tabriz, Iran: a discursive transformation of a bilingual space into a monolingual place / S. H. Mirvahedi // International Journal of the Sociology of Language. - 2016. - № 242. - P. 195-216. Moriarty, M. Languages in motion: multilingualism and mobility in the linguistic landscape / M. Moriarty // International Journal of Bilingualism. - 2014. - Vol. 18, № 5. - P. 457-463.

Mustajoki, A. Russification of Western concepts: political will and crisis in a Russian way / A. Mustajoki, E. Protassova // Understanding Russianness / ed. by R. Alapuro, A. Mustajoki, P. Pesonen. - New York : Routledge, 2012. P. $32-52$.

Muth, S. Russian language abroad: Viewing language through the lens of commodification / S. Muth // Russian Journal of Linguistics. - 2017. - Vol. 21, № 3. - P. 463-675.

Pavlenko, A. Language conflict in post-Soviet linguistic landscapes / A. Pavlenko // Journal of Slavic Linguistics. 2009. - Vol. 17, № 1-2. - P. 247-274.

Pavlenko, A. Transgression as the Norm: Russian in Linguistic Landscape of Kyiv, Ukraine / A. Pavlenko // Gorter et al. -2012 . - P. 36-56.

Pavlenko, A. Why diachronicity matters in the study of linguistic landscapes / A. Pavlenko, A. Mullen // Linguistic Landscape. - 2015. - Vol. 1, № 1/2. - P. 114-132.

Perotto, M. The presence of the Italian language in the linguistic landscapes of Moscow / M. Perotto // Dimensions of Sociolinguistic Landscapes in Europe: Materials and methodological solutions / ed. by M. Laitinen, A. Zabrodskaja. Frankfurt a.M. : Lang, 2015. - P. 263-282.

Pietikäinen, S. Frozen actions in the Arctic linguistic landscape: A nexus analysis of language processes in visual space / S. Pietikäinen, P. Lane, H. Salo, S. Laihiala-Kankainen // International Journal of Multilingualism. - 2011. Vol. 8, No 4. - P. 277-298.

Rasinger, S. M. Linguistic landscapes in Southern Carinthia (Austria) / S. M. Rasinger // Journal of Multilingual and Multicultural Development. - 2014. - Vol. 35, № 6. - P. 580-602.

Robbek, V. Language situation in the Sakha Republic (Yakutia) / V. Robbek // Bicultural Education in the North: Ways of Preserving and Enhancing Indigenous Peoples' Languages and Traditional Knowledge / ed. by E. Kasten. Münster : Waxmann, 1998. - P. 113-122.

Rychkov, S. I. Ethnically marked linguistic landscape of Kazan / S. I. Rychkov, N. V. Rychkova // Paper presented at the Sociolinguistics Symposium 19, 21.-24.8. - Berlin : Freie Universität, 2012. - P. 120-121.

Salánki, S. The Present-Day Situation of the Udmurt Language : A Ph.D. Thesis / Salánki S. - Budapest : Eötvös Loránd University, 2007. - 12 p.

Sebba, M. Ideology and alphabets in the former USSR / M. Sebba // Language Problems and Language Planning. 2006. - Vol. 30, № 2. - P. 99-125.

Shohamy, E. Linguistic Landscape in the City / E. Shohamy, E. Ben-Rafael, M. Barni. - Clevedon : Multilingual Matters, 2010. $-384 \mathrm{p}$.

Tafoya, S. M. The linguistic landscape of California schools / S. M. Tafoya // California Counts. - 2002. - Vol. 3, No 4. - P. 1-14.

The small indigenous nations of Northern Russia. A guide for researchers. Vol. 29 / ed. by D. A. Funk, L. Sillanpää. Åbo Academy University, Social Science research Unit, 1999. - XII, 184 p.

Tsypanov, E. Language and ethnic mobilization among the Komi in the post-Soviet period / E. Tsypanov // Nationalities Papers: The Journal of Nationalism and Ethnicity. - 2001. - Vol. 29, № 1. - P. 109-128. 
Tufi, S. Trademarks in the linguistic landscape: methodological and theoretical challenges in qualifying brand names in the public space / S. Tufi, R. Blackwood // International Journal of Multilingualism. - 2010. - Vol. 7, № 3. P. 197-210.

Wright, S. Language Policy and Language Planning. From Nationalism to Globalisation / S. Wright. - Basingstoke : Palgrave Macmillan, 2004. - $311 \mathrm{p}$.

Yelenevskaya, M. Global Russian: between decline and revitalization / M. Yelenevskaya, E. Protassova // Russian Journal of Communication. - 2015. - Vol. 7, № 2. - P. 139-149.

Yelenevskaya, M. Linguistic landscape and what it tells us about the integration of the Russian language into Israeli economy / M. Yelenevskaya, L. Fialkova // Russian Journal of Linguistics. - 2017. - Vol. 21, № 3. - P. 557-586.

\section{References}

Akunin, B. (2012). = Borisova, A. Kreativshchik [Creative]. Moscow, Astrel'. 315 p.

Akunin, B. (2011a). = Borisova, A. Tam... [There...]. Moscow, Astrel'. 320 p.

Akunin, B. (2011b). = Borisova, A. Vremena goda [Seasons]. Moscow, Astrel'. $480 \mathrm{p}$.

Alos i Font, H. (2019). Russian, Chuvash and English: Minority-Language Activism, Tourism Promotion and the Evo-

lution of Municipal Advertisements in Shupashkar/Cheboksary (2015-2018). In Nikunlassi, A., Protassova, E. (Eds.).

Russian Language in the Multilingual World. Helsinki, University of Helsinki, pp. 68-86.

Angermeyer, P. S. (2005). Spelling Bilingualism: Script choice in Russian American classified ads and signage.

In Language in Society. Vol. 34. No. 4, pp. 493-531.

Aristova, N. (2016). English Translations in the Urban Linguistic Landscape as a Marker of an Emerging Global City:

The Case of Kazan, Russia. In Procedia - Social and Behavioral Sciences. No. 231, pp. 216-222.

Aronin, L., Singleton, D. (2012). Multilingualism. Amsterdam, Benjamins. 230 p.

Backhaus, P. (2007). Linguistic Landscapes: A Comparative Study of Urban Multilingualism in Tokyo. Clevedon, Multilingual Matters. 158 p.

Badmatsyrenova, D., Elivanova, A. (2008). Language Policy in Russia: The Case Study of the Yakut Language. In The Northern Research Forum Secretariat. The Borderless North. Akureyri, University of Akureyri Research Centre, pp. 215-218.

Baranova, V. V., Fedorova, K. S. (2017). (Ne)vidimost' i (vne)nakhodimost': trudovye migranty i jazykovoi landshaft

Sankt-Peterburga [(In)visibility and (Out of)discoverability: Labor Migrants and the Language Landscape of Saint Petersburg]. Gorodskie issledovanija i praktiki. Vol. 2. No. 1, pp. 103-121.

Bruyèl-Olmedo, A., Juan-Garau, M. (2009). English as a Lingua Franca in the Linguistic Landscape of the Multilingual Resort of S'Arenal in Mallorca. In International Journal of Multilingualism. Vol. 6. No. 4, pp. 386-411.

Chudinovskikh, O. S. (2011). Statisticheskoe obespechenie migratsionnoi politiki RF. Migratsionnyi barometr v Rossiiskoi Federatsii [Statistical Support of the Migration Policy of the Russian Federation. Migration Barometer in the Russian Federation]. Moscow, MAKS Press. $44 \mathrm{p}$.

Chudinovskikh, O., Denisenko, M. (2017). Russia: A Migration System with Soviet Roots. In Migration Policy Institute, Migration Information Source. May 18. URL: migrationpolicy.org/article/russia-migration-system-soviet-roots (mode of access: 28.05 .2021$)$.

Coluzzi, P. (2009). The Italian Linguistic Landscape: the Cases of Milan and Udine. In International Journal of Multilingualism. Vol. 6. No. 3, pp. 298-312.

Dufva, H., Pietikäinen, S. (2009). Moni-ilmeinen Monikielisyys. In Puhe ja kieli. Vol. 29. No. 1, pp. 1-14.

Edelman, L. (2014). The Presence of Minority Languages in Linguistic Landscapes in Amsterdam and Friesland (the Netherlands). In International Journal of the Sociology of Language. No. 228, pp. 7-28.

Funk, D. A., Sillanpää, L. (Eds.). (1999). The Small Indigenous Nations of Northern Russia. A guide for Researchers. Vol. 29. Åbo Academy University, Social Science research Unit. XII, 184 p.

Cenoz, J., Gorter, D. (2006). Linguistic Landscape and Minority Languages. In International Journal of Multilingualism. Vol. 3. No. 1, pp. 67-80.

Gorter, D. (2006). Introduction: The Study of the Linguistic Landscape as a New Approach to Multilingualism. In International Journal of Multilingualism. Vol. 3. No. 1, pp. 1-6.

Gorter, D., Marten, H. F., Van Mensel, L. (Eds.). (2012). Minority Languages in the Linguistic Landscape. New York, Palgrave Macmillan. XII, $347 \mathrm{p}$.

Graney, K. E. (2010). Of Khans and Kremlins: Tatarstan and the Future of Ethno-Federalism in Russia. Plymouth, Lexington Books. XII, $288 \mathrm{p}$.

Grishaeva, E. B. (2015). Linguistic Landscape of the City of Krasnoyarsk. In Procedia-Social and Behavioral Sciences. No. 200 , pp. 210-214.

Hämäläinen, M. (2021). Endangered Languages are Not Low Resourced! In Hämäläinen, M., Partanen, N., Alnajjar, K. (Eds.). Multulingual Facilitation. Helsinki, University of Helsinki, pp. 1-11.

Kazakhstan. Perekhod na latinitsu [Kazakhstan. Switching to Latin]. (2017). In Sputniknews.kz. 12.04. URL: ru.sputniknews.kz/trend/latinica_12042017/?mobile_return=yes\&_ga $=2.100417622 .932187546 .1542144213-848727409.1542144213$ (mode of access: 28.05.2021).

Khakimov, E. R., Trusova, E. G. (2010). Russkii yazyk kak lingva franka v respublike Udmurtiya [Russian as a Lingua Franca in the Republic of Udmurtia]. In Mustajoki, A., Protassova, E., Vakhtin, N. (Eds.). Instrumentarium of Linguistics: Sociolinguistic Approaches to Non-Standard Russian. Helsinki, University of Helsinki, pp. 127-138.

Khudoikulova, N. (2015). Linguistic Situation in Tajikistan: Language Use in Public Space. In Russian Journal of Communication. Vol. 7. No. 2, pp. 164-178. 
Klementyev, Y., Kovaleva, S., Zamyatin, K. (2012). The Karelian Language in Russia: An Overview of a Language in Context. In Working Papers in European Language Diversity 12. Mainz etc., European Language Diversity for All (ELDIA). $14 \mathrm{p}$.

Kreslins, J. (2003). Linguistic Landscapes in the Baltic. In Scandinavian Journal of History. Vol. 28. No. 3-4, pp. $165-174$. Kutlay, Y., Kroon, S. (2003). Ethnolinguistic Vitality Perceptions and Language Revitalization in Bashkortostan. In Journal of Multilingual and Multicultural Development. Vol. 24. No. 4, pp. 319-336.

Itagi, N. H., Kumar Singh, S. (Eds.). (2002). Linguistic Landscaping in India, with Particular Reference to the New States. Mysore, Central Institute of Indian Languages. XII, 255 p.

Ivković, D. (2013). Pragmatics Meets Ideology: Digraphia and Non-Standard Orthographic Practices in Serbian Online News Forums. In Journal of Language and Politics. Vol. 12. No. 3, pp. 335-356.

Lado, B. (2011). Linguistic Landscape as a Reflection of the Linguistic and Ideological Conflict in the Valencian Community. In International Journal of Multilingualism. Vol. 8. No. 2, pp. 135-150.

Lallukka, S. (1990). The East Finnic Minorities in the Soviet Union. An Appraisal of the Erosive Trends. Jyväskylä, Gummerus. 344 p.

Landry, R., Bourhis, R. Y. (1997). Linguistic Landscape and Ethnolinguistic Vitality. An Empirical Study. In Journal of Language and Social Psychology. Vol. 16. No. 1, pp. 23-49.

Litvinskaya, A. A. (2010). Linguistic Landscape of "Little Russia by the Sea", a Multilingual Community in a Brooklyn Area of New York City. A Ph.D. Thesis. Indiana University of Pennsylvania. 186 p.

Mirvahedi, S. H. (2016). Linguistic Landscaping in Tabriz, Iran: a Discursive Transformation of a Bilingual Space into a Monolingual Place. In International Journal of the Sociology of Language. No. 242, pp. 195-216.

Moriarty, M. (2014). Languages in motion: multilingualism and mobility in the Linguistic Landscape. In International Journal of Bilingualism. Vol. 18. No. 5, pp. 457-463.

Mustajoki, A., Protassova, E. (2012). Russification of Western Concepts: Political Will and Crisis in a Russian Way. In Alapuro, R., Mustajoki, A., Pesonen, P. (Eds.). Understanding Russianness. New York, Routledge, pp. 32-52.

Muth, S. (2017). Russian Language Abroad: Viewing Language through the Lens of Commodification. In Russian Journal of Linguistics. Vol. 21. No. 3, pp. 463-675.

Orekhov, B., Reshetnikov, K. (2016). Gosudarstvennye yazyki Rossii v Vikipedii: K voprosu o setevoi aktivnosti minoritarnykh yazykovykh soobshchestv [State Languages of Russia on Wikipedia: On the Issue of the Network Activity of Minority Language Communities]. In Lapina-Kratasyuk, E. G., Moroz, O. V., Nim, E. G. (Eds.). Nastroika yazyka: upravlenie kommunikatsiyami na postsovetskom prostranstve. Moscow, NLO, pp. 263-281.

Pavlenko, A. (2009). Language Conflict in Post-Soviet Linguistic Landscapes. In Journal of Slavic Linguistics. Vol. 17. No. 1-2, pp. 247-274.

Pavlenko, A. (2012). Transgression as the Norm: Russian in Linguistic Landscape of Kyiv, Ukraine. In Gorter et al., pp. 36-56.

Pavlenko, A., Mullen, A. (2015). Why Diachronicity Matters in the Study of Linguistic Landscapes. In Linguistic Landscape. Vol. 1. No. 1/2, pp. 114-132.

Perotto, M. (2015). The Presence of the Italian Language in the Linguistic Landscapes of Moscow. In Laitinen, M., Zabrodskaja, A. (Eds.). Dimensions of Sociolinguistic Landscapes in Europe: Materials and methodological solutions. Frankfurt a.M., Lang, pp. 263-282.

Petrova, N. (2017). Migrant s natury. Kto teper' edet rabotat' v Rossiyu [A Migrant from Nature. Who is Now Going to Work in Russia]. In Kommersant. 12.08. URL: kommersant.ru/doc/3380376?utm_campaign=push\&utm_source=kommersant (mode of access: 28.05.2021).

Pietikäinen, S., Lane, P., Salo, H., Laihiala-Kankainen, S. (2011). Frozen Actions in the Arctic Linguistic Landscape: A Nexus Analysis of Language Processes in Visual Space. In International Journal of Multilingualism. Vol. 8. No. 4, pp. 277298.

Protassova, E. (2013). Russkii yazyk v turisticheskom landshafte zarubezhya [Russian Language in the Tourist Landscape Abroad]. In Russkii yazyk za rubezhom. No. 5, pp. 53-61.

Protassova, E. (2015). Variativnost' lingvisticheskogo landshafta Rossii [Variation of the Linguistic Landscape of Russia]. In Ekologiya yazyka i kommunikativnaya praktika. No. 4, pp. 91-102.

Protassova, E., Shchemerova, N. (2014). Mnogoyazychie v oblike regionov Rossii [Multilingualism in the Guise of Russian Regions]. In Magidovich, M. (Ed.). Sovremennye modeli razvitiya kul'turnykh industrii v regionakh Rossii. Saint Petersburg, RGPU im. A.I. Gertsena, pp. 189-194.

Rasinger, S. M. (2014). Linguistic Landscapes in Southern Carinthia (Austria). In Journal of Multilingual and Multicultural Development. Vol. 35. No. 6, pp. 580-602.

Robbek, V. (1998). Language Situation in the Sakha Republic (Yakutia). In Kasten, E. (Ed.). Bicultural Education in the North: Ways of Preserving and Enhancing Indigenous Peoples' Languages and Traditional Knowledge. Münster, Waxmann, pp. 113-122.

Rozina, R. I. (2007). Chuzhie i svoi slova na moskovskikh ulitsakh [Strangers and Their Own Words on Moscow Streets]. In Zemskaya, E. A., Kalenchuk, M. L. Yazyk v dvizhenii. K 70-letiyu L. P. Krysina. Moscow, Yazyki slavyanskoi kul'tury, pp. 491-505.

Rychkov, S. I., Rychkova, N. V. (2012). Ethnically Marked Linguistic Landscape of Kazan. In Paper presented at the Sociolinguistics Symposium 19, 21.-24.8. Berlin, Freie Universität, pp. 120-121.

Salánki, S. (2007). The Present-Day Situation of the Udmurt Language. A Ph.D. Thesis. Budapest, Eötvös Loránd University. $12 \mathrm{p}$.

Sebba, M. (2006). Ideology and Alphabets in the Former USSR. In Language Problems and Language Planning. Vol. 30. No. 2, pp. 99-125. 
Shohamy, E., Ben-Rafael, E., Barni, M. (2010). Linguistic Landscape in the City. Clevedon, Multilingual Matters. 384 p. Shohamy, E., Gorter, D. (Eds.). (2008). Linguistic Landscape: Expanding the Scenery. London, Routledge. 392 p.

Sidorova, L. A., Ferguson, G., Vallikivi, L. (2014). Lingvisticheskii landshaft severnogo poselka kak produkt kul'turnykh industrii (na primere p. Cherskii Respubliki Saha (Yakutiya)) [The Linguistic Landscape of the Northern Village as a Product of the Cultural Industry (on the Example of Chersky Village of the Sakha Republic (Yakutia))]. In Magidovich, M. (Ed.). Sovremennye modeli razvitiya kul'turnykh industrii v regionakh Rossii. Saint Petersburg, RGPU im. A.I. Gertsena, pp. 195-204.

Tafoya, S. M. (2002). The Linguistic Landscape of California Schools. In California Counts. Vol. 3. No. 4, pp. 1-14.

Toivanen, R., Saarikivi, J. (Eds.) (2016). Linguistic Genocide or Superdiversity? New and Old Language Diversities. Bristol, Multilingual Matters. 362 p.

Torokhova, E. A. (2012). Yazykovaya politika v Udmurtskoi respublike [The Language Policy in the Udmurt Republic]. In Vestnik Udmurtskogo universiteta. Seriya istoriya i filologiya. No. 2, pp. 152-158.

Tsypanov, E. (2001). Language and Ethnic Mobilization among the Komi in the Post-Soviet Period. In Nationalities Papers: The Journal of Nationalism and Ethnicity. Vol. 29. No. 1, pp. 109-128.

Tufi, S., Blackwood, R. (2010). Trademarks in the Linguistic Landscape: Methodological and Theoretical Challenges in Qualifying Brand Names in the Public Space. In International Journal of Multilingualism. Vol. 7. No. 3, pp. 197-210.

Wright, S. (2004). Language Policy and Language Planning. From Nationalism to Globalisation. Basingstoke, Palgrave Macmillan. 311 p.

Yelenevskaya, M., Fialkova, L. (2017). Linguistic Landscape and What It Tells Us about the Integration of the Russian Language into Israeli Economy. In Russian Journal of Linguistics. Vol. 21. No. 3, pp. 557-586.

Yelenevskaya, M., Protassova, E. (2015). Global Russian: between Decline and Revitalization. In Russian Journal of Communication. Vol. 7. No. 2, pp. 139-149.

Zamyatin, K., Saarikivi, J., Pasanen, A. (2012). Kak i zachem sokhranyat' yazyki narodov Rossii? [How and Why Should the Languages of the Peoples of Russia Be Preserved?]. Vammala, POGA. 181 p.

\section{Данные об авторе}

Протасова Екатерина Юрьевна - кандидат филологических наук, доктор педагогических наук, адъюнкт-профессор, доцент, Отделение языков, Хельсинкский университет (Хельсинки, Финляндия). land.

Адрес: P.O. Box 24, 00014 University of Helsinki, Fin-

E-mail: ekaterina.protassova@helsinki.fi.

\section{Author's information}

Protassova Ekaterina Yurievna - Candidate of Philology, Doctor of Pedagogy, Adjunct Professor, Associate Professor, Department of Languages, University of Helsinki (Helsinki, Finland). 